\title{
WHO IS COMING TO THE ARTEFACTUAL FIELD EXPERIMENT? PARTICIPATION BIAS AMONG CHINESE RURAL MIGRANTS
}

\author{
Paul Frijters \\ Tao Sherry Kong \\ Elaine M. Liu \\ Working Paper 20953 \\ http://www.nber.org/papers/w20953 \\ NATIONAL BUREAU OF ECONOMIC RESEARCH \\ 1050 Massachusetts Avenue \\ Cambridge, MA 02138 \\ February 2015
}

\begin{abstract}
We would like to thank Xin Meng for helpful discussion and Adam Reger for providing editorial assistance. The collection of the RUMICI data used in this paper is financed by IZA, ARC/AusAid, the Ford Foundation, and the Ministry of Labor and Social Security of China. Elaine Liu thanks Chiang Ching-kuo Foundation for financial support. The views expressed herein are those of the authors and do not necessarily reflect the views of the National Bureau of Economic Research.
\end{abstract}

NBER working papers are circulated for discussion and comment purposes. They have not been peerreviewed or been subject to the review by the NBER Board of Directors that accompanies official NBER publications.

(C) 2015 by Paul Frijters, Tao Sherry Kong, and Elaine M. Liu. All rights reserved. Short sections of text, not to exceed two paragraphs, may be quoted without explicit permission provided that full credit, including $(\odot$ notice, is given to the source. 
Who Is Coming to the Artefactual Field Experiment? Participation Bias among Chinese Rural Migrants

Paul Frijters, Tao Sherry Kong, and Elaine M. Liu

NBER Working Paper No. 20953

February 2015

JEL No. C81,C90,C93

\begin{abstract}
In this paper, we compare participants in an artefactual field experiment in urban China with the survey population of migrants from which they were recruited. The experimental participants were more educated, more likely to lend money to friends, and worked fewer hours than the general population. They differ significantly from non-participants in terms of regression coefficients, such as the effects of wealth and marital status on the probability of being self-employed and distance migrated. We thus find that there was selection into our experiments on the basis of both observable characteristics and on unobserved differences in behavioral relations.
\end{abstract}

\author{
Paul Frijters \\ Department of Economics \\ Elaine M. Liu \\ University of Queensland \\ Department of Economics \\ St Lucia, Brisbane, Qld 4072 Australia \\ University of Houston \\ p.frijters@uq.edu.au \\ McElhinney Hall 223D \\ Houston, TX 77004 \\ and NBER \\ Tao Sherry Kong \\ emliu@uh.edu \\ Institute of Social Science Survey \\ Peking University \\ Haidian District, Beijing, China \\ tao.kong@pku.edu.cn
}




\section{Introduction}

Choice experiments are increasingly relied on in economics to glean information about subjects' preferences and behavioral traits. A key question about choice experiments, whether in the lab or in the field, is the external validity of the results. This hinges on whether the behavior displayed is natural, and on whether the behavior of subjects who participate in the experiments is representative of larger populations. ${ }^{1}$ This paper addresses this second issue by comparing participants in an artefactual field experiment ${ }^{2}$ in China with the survey population of migrants from which they were recruited.

Selectivity of experimental subjects is a problem for generalizability if the experimental participants are not representative of the groups of interest and if behavior differs significantly by group: if behavior does not differ by group, selectivity does not matter. We thus look both at the selectivity of participants and at whether their estimated behavioral patterns differ from nonparticipants; i.e., whether regression coefficients on important variables for outcomes of particular interest vary with participation in the experiment.

Lab experiments conducted in universities are usually done with university students. They are clearly selective in that students who show up for experiments are not representative of the non-student population, and might not even be representative of the general student population. For example, Camerer and Lovallo (1999) find that students' entry into competition games depends on their level of overconfidence and that participating students thus differ from the general student population.

\footnotetext{
${ }^{1}$ See Harrison and List (2004) for more elaborate details of this criticism and Deaton (2009) for a wider discussion of the limits of what can be learned by experiments. Other papers that also examine related issues include Harrison et al. (2009), Lazear et al. (2012), Levitt and List (2007), Von Gaudecker et al. (2012), Cleave et al. (2013), Falk et al. (2013), and Andersen et al (2013).

${ }^{2}$ In the taxonomy of Harrison and List (2004), artefactual field experiments include a conventional lab experiment but with a nonstandard subject pool.
} 
Whether the behavior of participating students differs from other groups in society is an active question in the literature. Anderson et al. (2013) find that students are less pro-social than the general population. In contrast, Falk et al. (2013) find that students behave similarly to the general population in terms of their revealed social preferences, including pro-social behavior and trust.

In the past few years, artefactual field experiments, which recruit subjects outside of universities, have tried to circumvent the problem of the selectivity of students. Yet artefactual field experiments could possibly face worse selection biases in recruitment compared to lab experiments that mainly involve university students. At the university level, both subjects and experimenters often belong to the same institution, making it easy for subjects to verify the authenticity and purpose of the experiment. This creates trust between experimenters and subjects, which would reduce the importance of trust and risk preferences for selection. In an artefactual field experiment, subjects and the experimenters often have little or no contact prior to the experiments, arguably making trust and risk preferences more important for the participation decision.

Also, university students need to go to university anyway for classes, making the marginal travel costs to university computer labs comparable for most potential participants. In the case of artefactual field experiments, however, the location and time costs of the experiment are crucial as they generate differential transaction costs for different populations, potentially worsening selectivity.

Additionally, the objective function of university students may be quite different from the objective function of other subjects. Slonim et al. (2013), for instance, postulate that student participation depends on income, leisure time, intellectual curiosity, and social preferences. 
These may not reflect the motivations of non-students: the participants in our experiments (rural migrants working in major Chinese cities) nearly all have full-time jobs and might put more weight on income than on intellectual curiosity and leisure time. They probably also face higher opportunity costs compared to university students. Our first objective is then to find out just how representative participation in our artefactual field experiment is. Determining whether the behavior of the participating migrants differs from the non-participating ones in terms of regression coefficients is the second objective of the paper.

The findings of this paper are of particular relevance to artefactual field experiments in developing countries. ${ }^{3}$ To our knowledge, our paper is the first to discuss participation bias in artefactual field experiments in a development setting, a literature in which it is not a common practice to report participation rates and hence for which it is largely unknown how bad the potential selectivity is. Our paper aims to serve as a useful benchmark for that literature. It furthermore adds to the existing literature on selectivity into artefactual field experiments (Harrison et al. 2009; and von Gaudecker et al. 2012) by having a survey of relatively poor migrants as the base population. It supplements the literature on selectivity in lab experiments with university students (Slonim et al. 2013; Krawczyk, 2011; Falk et al. 2013).

\section{Preview of results and brief data introduction}

The dataset we use as our base is the Urban Migrant Survey (UMS), which includes 5,240 migrant households across 15 cities in China in 2009. This survey contains detailed information

\footnotetext{
${ }^{3}$ Our work is most applicable to those papers that recruit subjects from working populations in an urban setting. This includes Dasgupta and Mani (2013), Dulleck et al. (2013), and Carpenter et al. (2004). See Cardenas and Carpenter (2008) for a review of earlier works.
} 
on many variables, including education, income, wealth, birth order, family size, a general risk preference measure, and general trust measures.

Within months after the survey, we invited all household heads from surveyed households to participate in an artefactual field experiment involving real lotteries. This experiment, which lasted about 2.5 hours, elicited particular traits— such as risk preferences, time preferences and trust measures, as well as cognitive ability. The fixed show-up fee was the equivalent of more than half a day's average wage (50 Yuan), and participants earned additional income depending on the outcome of the experiments. Despite our efforts to make the experiment accessible by scheduling multiple sessions in the evenings and on the weekends, and along with the nonnegligible compensation, only one-third of the initial survey respondents decided to participate in the experiments.

Using the UMS dataset, we examine the differences in characteristics between experiment participants (EP) and non-experiment participants (NEP). We find that the EPs, on average, are more educated, are more likely to lend money to their friends, have a higher risk tolerance, and work fewer hours. This is in line with what one would expect from the point of view of experimental subjects being more risk-taking. While we expected a lack of trust in the survey agency to play a role, we do not find any consistent pattern in the self-assessed trust measure between EP and NEPs. Nor do we find any difference in hourly wages, meaning that opportunity costs do not provide a robust explanation for the selection. Rather, we seem to select on whether someone is young and adventurous.

We look at whether selectivity matters by checking two commonly examined relations in the field of migration economics, where we look for parameter heterogeneity in the coefficient estimates across EP/NEP groups. If the coefficient estimates for the two groups are drastically 
different, then we interpret this as selectivity on relationships between observable variables. It would mean that the relations found between the observed characteristics of lab participants do not provide an inference for the same relationship in the underlying population. We indeed find statistically robust evidence that the results from regressions we often see in the literature differ for the NEPs versus the EPs, though in absolute terms the differences are small.

The paper proceeds as follows: Section 2 provides a literature review. Section 3 describes the survey methodology and the experimental methodology. Section 4 gives summary statistics and analyzes the participation decision. Section 5 provides evidence of the importance of selection for estimates of underlying relations and gives a suggested interpretation. Section 6 concludes.

\section{Literature review}

Is there selectivity and does behavior differ by group? We approach the literature on these two constituents of participation bias as pertaining to students and non-students separately.

\section{Participation Bias of Student Subjects}

Most lab experiments use students as subjects, leading to numerous studies comparing students who participate with students who do not (Peterson 2001; Carpenter, Burks, and Verhoogen 2005; Carpenter, Connolly, and Myers 2008).

Slonim et al. (2013) look at which students of an initial pool of surveyed students participate in lab experiments and found, somewhat surprisingly, that more risk-averse individuals were more likely to participate. They attributed this result to the sizable payoff and to there being little perceived risk to participation. 
In contrast, Falk et al. (2013) used an unrelated donation decision to compare the pro-social inclinations of students who participated in experiments and of students who did not participate, finding no significant differences. Cleave et al. (2013) used classroom experiments to gain knowledge of the preferences of the recruitment population before they compared those from the classroom population who chose to participate with those who did not. Similar to Falk et al. (2013), they found no presence of significant selection bias among students who participated in the lab experiments.

A number of studies varied participation incentives to generate selectivity. For example, Rutström (1998) explored the role of recruitment fees in attracting experimental participants and concluded that changes in fees created group differences (e.g., male versus female, white versus non-white) in some but not all treatments. Krawczyk (2011) varied pecuniary and non-pecuniary benefits of experiments, documenting significant differences in corresponding experimental subject pools.

On behavior and selectivity, Anderson et al. (2013) find that students are less pro-social than the general population, but Falk et al. (2013) find no such difference.

There are thus conflicting results on the issues of both selectivity and heterogeneity in behavior across studies looking for participation bias among laboratory experiments that use students as subjects, which may be related to the studies being done in different countries with underlying student pools that differ in their attitudes toward experiments. This makes it useful to look at more subject pools and different contexts.

\section{Participation Bias of Non-Student Subjects}


In terms of selectivity of participants in non-student populations, Harrison et al. (2009) study the participation bias in both lab and artefactual field experiments in Denmark, finding that higher show-up fees generated samples of more risk-averse participants for artefactual field experiments.

Von Gaudecker et al. (2012) look at behavioral differences between different subject pools in lab experiments in the Netherlands. They first found that behavior differed between those doing experiments on the internet versus those doing experiments in the lab. Furthermore, they found that university student populations had lower levels of risk aversion and loss aversion compared to samples from the general population, suggesting that behavior indeed differs between the "usual lab participants" and the general population.

On the issue of behavioral differences more generally, experimental results have been found to vary across broad population groups, such as by age, occupation, and nationality (Benz and Meier 2008; Baran et al. 2010; Cleave et al. 2013), suggesting a large potential role for participation bias. Similarly, Belot et al. (2010) compared behavior between students and nonstudents, finding that students are more likely to behave as homo economicus agents than nonstudents in games involving other-regarding preferences (for example, dictator games, trust games, and public good games). In games that do not engage other-regarding preferences (for example, beauty contests and second-price auctions), they found only limited evidence of differences in behavior between subject pools. Falk et al. (2013) similarly found non-student participants to be more pro-social.

Summarizing these various strands, no robust lessons have as yet emerged: selectivity is important for some subject pools, but not others, and some behavior varies, but not all behavior. 
And we know virtually nothing on these issues for artefactual field experiments in developing countries. Our paper thus contributes to an unresolved and ongoing debate.

\section{The Survey and Recruitment into the Experiment}

The dataset used in this paper comes from the 2009 Urban Migrant Survey (UMS) in China, which took place from March/April to July of $2009 .{ }^{4}$ The UMS covers 15 cities across nine provinces or metropolitan areas, selecting 5,240 migrant households randomly from a minicensus of representative enumeration areas in each city, which forms the population from which we recruited participants for artefactual field experiments. ${ }^{5}$ The face-to-face interviews elicited detailed information about every family member living in the surveyed household, and included questions about work, family expenditures, income, health, social networks, subjective risk preferences, and trust measures.

Each household head of the 2009 survey received multiple calls and texts in the months following the survey. ${ }^{6}$ They were reminded that they had participated in the UMS survey and were invited to participate in an individual preference experiment. They would receive 50 Yuan as a show-up fee (more than half a day's wage) to compensate for transportation costs and time.

\footnotetext{
${ }^{4}$ This is a part of the Rural-Urban Migration in China and Indonesia (RUMiCI) research project, which includes a longitudinal survey in both countries. For more details about the RUMiC sample scheme, the distinction between the head of the household and the respondent, as well as the use of proxy-respondents, see http://rumici.anu.edu.au/ or Chapter 7 of Meng et al. (2010).

${ }^{5}$ Within each city, all data collection occurred within a one-month period.

${ }^{6}$ This started in mid-June, with some cities having the experiment as late as September 2009. The phone methodology was dictated by local circumstances: in a developing country, survey participants often do not have email addresses, nor do they come to particular areas where they would see posters or other advertising material, as students in universities do. Yet in 2007, China had a high mobile phone coverage rate of $93 \%$ of the urban population (China Telecommunication Report 2007), while email coverage was scant. Also, calls could be made in a standardized manner and we could better ensure that identical information was provided to all potential participants. In our case, all subjects who participated in the survey had given us their phone numbers (we did not ask for their email addresses). We called all potential participants at most three times. In contrast, most other papers that use artefactual field experiments do not report their recruiting methods or their participation rates. The few papers that we could find that reported recruiting methods used a wide range of options, including face-to-face requests, snowball sampling, and soliciting phone interviews. None discuss their participation rates.
} 
They were told the experiment would take approximately 2.5 hours and that there would be an additional payoff depending on the outcomes of strategic games and lotteries. If they could not participate in person, we asked if their spouses would be able to come. If they agreed to participate, they were given a list of available sessions at the designated venue, usually rented school classrooms or conference rooms at hotels in the center of each city. ${ }^{7}$ The experimental sessions were mostly on the weekends, to suit a variety of working schedules. Out of the 5,240 households we contacted, 1,693 households sent a "valid participant" for whom we have survey information and self-reported preference measures, including 1,601 household heads (94.5\%), 74 spouses (4.4\%), and $18(1.1 \%)$ other household members.

Each of the participants would complete experimental modules consisting of four partsincluding a set of lotteries eliciting risk preferences, a set of lotteries eliciting time preferences, a game eliciting their attitudes on trust and trustworthiness, and a 30-minute Raven's Progressive Matrices test measuring their cognitive ability. We omit a detailed discussion of these experiments in this paper, and simply mention that they were fairly standard economic experiments. ${ }^{8}$

Given that the EP sample contains a particular proportion of household heads, spouses, and others, there are various ways to construct the appropriate counterfactual NEP sample. Since our primary experimental target was the household heads who were present during the time of

\footnotetext{
${ }^{7}$ As one referee pointed out, the distance from the subject's household to the city center is a proxy for transaction cost and could be predictive of their likelihood to participate in the experiments. Unfortunately, we do not have that information, but we can say that residing in the city center is extremely expensive and nearly all migrant workers live on the outskirts of the city.

${ }^{8}$ To our knowledge, other than the Mexican Family Life Survey (MxFLS), this is the only other large-scale panel dataset to include such an elaborate version of an experimental module with real lotteries. Most other large representative samples, including the Italian Survey of Household Income and Wealth (SHIWor the Health and Retirement Survey (Barsky et al. 1997), as well as the CentER Savings Survey in the Netherlands (Donkers et al. 2001), measure risk preferences with abstractly framed, hypothetical lotteries. The German Socioeconomic Panel (SOEP) does include 450 subjects who were also involved in a real lottery, but in their case the lotteries were conducted by trained interviewers visiting subjects' houses (Dohmen et al. 2011).
} 
the survey (which held for 4,967 surveys out of the 5,240 surveys in total), the most straightforward comparison is between the household heads who attended both survey and experiments to the household heads who attended the survey but did not attend the experiments. Sample 1 then includes 1,601 EP and 3,366 NEP household heads.

In order to use the information on the non-household heads who attended the experiments, we created a second NEP sample as the relevant baseline population by randomly adding spouses and other relatives to the NEP sample to achieve $4.4 \%$ spouses and $1.1 \%$ other household members, mimicking the EP sample. Essentially, the distinction between Sample 1 and Sample 2 is that Sample 1 consists of household heads who participated in the experiment and household heads who did not participate in experiment. Sample 2 consists of households that sent a valid participant and households that did not send a valid participant. ${ }^{9}$

\section{Who Comes to the Artefactual Field Experiment?}

\subsection{Differences in descriptive statistics}

In Table 1, column 1, we show the summary statistics of the household heads in Sample 1 who had participated in the experiments and, in column 2, of the heads who did not participate in the experiments. In column 3 we show the summary statistics of the EP part of Sample 2, with column 4 showing the concomitant averages for the NEP. Table 1 reveals minor differences between Sample 1 and Sample 2: Sample 2 contains more females and fewer married individuals, which makes sense as Sample 2 includes spouses and children of household heads.

\footnotetext{
${ }^{9}$ Sample 2 includes 1,693 households that sent valid participants and 3,513 households that did not send a valid participant. Valid participants are those who were present at the main survey, so we have their self-reported risk and trust measures. Numbers of households do not add up to 5,240 because we want to maintain the same proportion of household representatives (household head, spouse, other members) in Sample 2 EP and NEP. We use a random draw of surveyed households to maintain the proportions, so some of the households were not included.
} 


\section{[Insert Table 1 About Here]}

Since the objective of the experiment was to elicit risk and trust attitudes, differences in them across EP and NEP groups are of primary interest. We can examine these differences by comparing the responses regarding trust and risk in the survey.

The risk-taking question in the survey was self-assessed: "Some people in a society are more likely to take risks while others are less likely. On a scale from zero to ten, where zero indicates you do not take any risks and ten indicates you like to take risks very much, could you please rank your own risk taking level?"

Table 1 shows that in both Sample 1 and Sample 2, experimental participants report a significantly higher degree of average risk-taking, contrary to what Slonim et al. (2013) found for lab participation among university students, which probably reflects the fact that travelling to participate in an experiment was considered an unusual and previously unknown activity for our baseline population.

There were two measures of trust in the survey, one self-assessed and one derived from revealed behavior. The trust question was "In general, do you think most people can be trusted or one should be careful when he/she deals with others. Select either 'Yes, most people can be trusted'; 'No, one should be careful'; or 'Do not know'." The revealed choice measure went: "Do you lend money or objects to your friends or acquaintances? Select either 'usually'; 'sometimes'; 'seldom'; 'never'.,

We found that experiment subjects were significantly more likely to have lent money to friends, but did not self-assess as having a higher or lower level of general trust than nonparticipants, suggesting that they are more trusting in their behavior though not in their selfperceived level of trust. 
The EP sample also differs from the NEP sample in other dimensions: the experiment participants were younger and were more likely to be migrants who are from the same province where the experiment took place; more likely to have a shorter distance from where they currently live to their hometown (laojia); more likely to have more years of schooling; more likely to work fewer hours; and less likely to be self-employed.

While these differences are highly significant, the size of these differences is small in a statistical sense: the difference in risk preferences, marital status, self-employment levels, age, and whether the respondent comes from the same province as the city in which (s)he lives, is about $1 / 10^{\text {th }}$ of a standard deviation. The biggest difference in observed characteristics is for education, with almost $2 / 10^{\text {th }}$ of a standard deviation.

[Insert Table 1 Panel A and Panel B About Here]

\subsection{Participation regressions}

To learn more about selectivity, Table 2 shows the coefficients in a linear probability model with the dependent variable being participation in the experiments and with the first four columns relating to Sample 1 and the next four to Sample 2, whereby more variables are added progressively within the sets of columns. We use random, nonparametric bootstraping to obtain standard errors.

The results in columns 1 and 4 show significant selection on trust and risk preferences when those are the only variables looked at: those who are more risk-loving and more likely to lend money to their friends are significantly more likely to show up for the experiments at the 
$1 \%$ and $10 \%$ significance levels, respectively. The coefficient on the self-reported measure of trust is negative, but insignificant. ${ }^{10}$

In columns 2, 3, 6, and 7, we include more individual characteristics as well as city-level fixed effects. These latter effects might be quite strong, because the experiments were organized by different local survey agencies in their respective cities. ${ }^{11}$ It is thus possible that some particular survey agencies worked harder than others at persuading their respondents to come to the experiment, affecting the selectivity of the sample over cities. In addition, migrants may also have some unobserved characteristics that differ across areas.

The risk and social preferences variables become insignificant when we control for other individual characteristics and city fixed effects for Sample 1, though risk preferences remain significant for Sample 2. Throughout the specifications, though, when we test for the joint significance of risk and trust measures combined, they are consistently significant at the $10 \%$ level (except column 3, in which the coefficients are the same, where the p-value is 0.12 ). There is hence weak support for the importance of risk and trust preferences in the participation decision.

Papers such as Andersen et al. (2009), Roe et al. (2009), and Slonim et al. (2013) also suggest that risk and uncertainty related to experiments can lead to a selection on participants' risk attitudes, though these papers pertained to students and Cleave et al. (2013) found no significant selection on risk attitudes. Our finding suggests that outside the university setting,

\footnotetext{
${ }^{10}$ This variable is statistically insignificant even when it is the only independent variable in the regression. There is no major issue of multicollinearity in this finding: the correlation between subjective risk and lending money to friends is only 0.13 . The correlation between subjective risk and trusting people is 0.08 . The correlation between lending money to friends and trusting people is 0.17 . The correlation between trusting people and being selfemployed is -0.065 .

${ }^{11}$ We hired a private survey company with a main office in Beijing and several branches in China to manage the survey collection and experiment process. In different cities, different persons would be in charge, potentially allowing for a divergence in recruitment effort.
} 
risk attitudes and trust (as proxied by lending money to friends) can play an important role in selection into experiments, probably because going to an experiment is a bigger deal for nonstudents.

The main other characteristic of importance is education: for every additional year of education, the probability of experimental participation increases by 0.8 to 0.9 percentage points. This tallies with previous papers that find or argue that intellectual curiosity can result in differences in participation (see the discussions in Levitt and List 2007; Kagel et al. 1979; and Slonim et al. 2013).

Interestingly, we find conflicting evidence for the hypothesis that opportunity costs drive participation. On the one hand, the coefficients for hourly wages are consistently insignificant and small. Yet we do find that those who work fewer hours are more likely to participate in all specifications.

In columns 3 and 7, we examine the nonlinearity of this work-hour effect. We divide subjects into four quartiles based on their weekly hours worked, and find that most of the negative effect of work hours is driven by those who are in the third and fourth quartiles: those who work 70 hours or more per week are less likely to show up. We also find that those who work for bigger firms are more likely to participate, perhaps because it is easier for them to take time off, suggesting that while selection might not operate on hourly wages, it does depend on the time demands of the job.

One important aspect of determining one's likelihood of attending the experiment could be the distance from the experimental location. To look at this indirectly (lacking information on 
subjects' place of residence ${ }^{12}$ ), we included a set of 150 district-of-workplace fixed effects in columns 4 and 8 . These dummies correspond to various districts in a city and capture some of the residence variation since many migrants live at their job. Comparing the results to those in columns 2 and 4, we are able to explain 5\% more of the variation in experimental participation when adding workplace areas. The set of dummies are jointly significant at $1 \%$ level, but in general the coefficients of observable characteristics remain unchanged, suggesting only a limited role for the distance to the experiment: all the participants had to actively take time off and travel to the experiments, a cost that will only have been marginally higher for those who needed to travel longer.

The results thus suggest that a lack of time constraints, a risk-taking and trusting attitude, and curiosity are the main predictors of participation in our artefactual field experiment.

[Insert Table 2 About Here]

\section{Possible impacts of the experimental selection on outcome variables}

In this section, we examine whether the self-selection bias in the experimental sample affects the representativeness of linear regression coefficients of interest. We do this by looking at whether the interaction between participation and variables of interest is significant. Such differences can be interpreted as differences in behavioral relations between the EP group and the NEP group. Since the regressions will include the variables already included for the selection equation, which are usually available in most surveys and some experiments too, any

\footnotetext{
${ }^{12} \mathrm{We}$ do not know their place of residence. This information is not available in the dataset we have access to. Additionally, even given the same geographic distance, transportation costs can be drastically different depending on precisely where in the city residents live, so a geographic distance calculated from a place of residence/workplace to an experimental location would be a very noisy measure of travel costs
} 
significance of this interaction can be interpreted as selectivity on unobserved characteristics that mediate effects. For instance, there might be unobserved personality traits that make it both more likely that someone goes to an experiment, but that also impact how observed characteristics relate to each other. "Curiosity" might thus affect participation as well as, for example, whether someone is self-employed, and might help some part of the population to get wealthier while impeding other parts of the population. Selection on such an unobserved trait would then lead to different effects in regressions of interest. Note that we make no claim at all about causality, merely as to whether the statistical relationship between observed characteristics is different for participants in experiments compared to non-participants.

\subsection{The correlates of self-employment and distance of migration}

In this sub-section, we want to test differences in coefficients between the EP and NEP samples for some commonly studied outcomes, including self-employment and distance of migration. These outcomes were chosen since both risk attitudes and trust arguably play major roles in these outcomes. The idea is to see whether regression coefficients in the experimental sample differ from the non-experimental sample.

In an earlier version of this paper, we examined outcomes commonly looked at in applied microeconomic research (income regressions, health regressions, and happiness regressions) and found significant (but modest) differences in regression coefficients between EP and NEP samples.

Table 3 presents the results for a linear probability model where the dependent variable is whether one is self-employed or not. Using a linear probability model allows us to include and interpret interaction terms between participation and several covariates. By contrast, the 
interpretation of interaction terms in a non-linear model, such as a probit or logit model, is less intuitive (Norton et al. 2004). Columns 1-3 use Sample 1 and columns 4-6 use Sample 2.

[Insert Table 3 About Here]

In column 1 we control only for basic individual characteristics with a set of city dummies that capture cross-city variation in self-employment industries, policy, etc. In column 1, age, wealth, being married, and years since migrated are all positively associated with being selfemployed; attitudes toward risk are positive but insignificant; those who are more trusting are less likely to be self-employed; and more years of education is negatively associated with being an entrepreneur. These are reasonable outcomes for migrants in urban China, as it takes several years of savings to be able to afford to be self-employed. While the opposite holds in many other development contexts where self-employment is a bottom-of-the-ladder activity, being selfemployed in urban China is very much a higher-paying and a higher entry-barrier occupation, often involving large loans from the family (thus favoring individuals who take fewer risks), and selecting those with less favorable outside options such as the lower-educated. ${ }^{13}$

In columns 2 and 3, we include the experimental participation dummy (EP) and a set of interaction terms between EP and other characteristics. In column 3, we add a set of interaction terms between city dummies and EP. The most significant interaction variables are wealth and marriage, showing that wealthier participants would be less likely to be self-employed than nonexperimental participants with the same wealth, while the married experimental participants are 7.1 percentage points less likely to be self-employed than the married non-participants. Compared to the coefficients among the NEP sample, these two interactions are $30 \%$ to $50 \%$ of the magnitude of their overall effect, showing that the relation between wealth/marriage and

\footnotetext{
${ }^{13}$ We cannot determine causality in these regressions. Thus, it is also possible that people who are entrepreneurs become wealthier and less trusting.
} 
being self-employed differs both statistically and substantially between the EP and the NEP samples.

The joint significance test at the bottom of the table shows that the null-hypothesis that the interaction coefficients are all zero, is rejected at the $1 \%$ significance level. The joint significance test for the "social parameters" also shows that the social preferences and risk preferences are jointly significant at the $10 \%$ level in determining entrepreneurship. In columns 4 to 6, we perform a similar analysis based on Sample 2 and find similar but statistically stronger results, reinforcing that there are significant interaction effects.

The outcome variable in Table 4 is the log of migration distance, which we take to be a measure of unfamiliarity between the migrant and the city in which he or she works. In columns 1 and 4, we control for basic individual characteristics and city dummies, just as in Table 3. In columns 2 and 5, we include a set of interaction terms between EP and various characteristics. In columns 3 and 6, we also add a set of interaction terms between city dummies and EP.

We find across the specifications that being female is correlated with migrating shorter distances and that being non-Han Chinese is associated with a longer distance of migration. Both of these are reasonable: females are typically found to be less risk-taking, and most ethnic minorities reside in the far Western/Southwestern provinces; therefore, the few non-Han Chinese in this sample would have migrated farther than their Han Chinese counterparts. Interestingly, conditional on gender, we do not find that self-reported risk preferences have any predictive power on the distance of migration. Lending money to friends is negatively correlated with the distance migrated, meaning that more trusting people migrate closer to their hometowns. An alternative explanation is that those who moved far from their hometowns are less likely to trust 
the friends around them and to lend them money. These results are similar for Sample 2, as reported in columns $4-6$.

Importantly, we test for the joint significance of EP and the set of interaction terms between EP and other characteristics. Similar to entrepreneurship, these interaction terms play an important role in determining the average distance of migration: we can reject the null hypothesis that the full set of interaction terms between the socio-economic characteristics are all zero in all columns at the $1 \%$ significance level. The greatest difference in the EP and NEP behavioral relations can be seen in log-wealth: for the NEP sample, high wealth is associated with significantly lower distance to migration, while among the EP sample, the opposite holds. Indeed, the effect is in absolute terms almost $150 \%$ higher for the EP sample and in the opposite direction $(+0.06$ versus -0.04$)$.

[Insert Table 4 About Here]

\subsection{A possible mechanism}

We were primarily interested in documenting the presence of selectivity and in whether participants in our artefactual field experiment were associated with different estimated coefficients in typical regressions of interest: we had no prior expectations of whether we would find something.

Ex post, though, what might account for the observed selectivity and found differences in regression coefficients across the EP and NEP samples? That is, what mechanism might one want to watch out for in subsequent work based on the results reported here? We suggest that a possible mechanism is provided by a personality trait like being "opportunistic", akin to "autonomy" and "curiosity". 
Consider that only one-third of the migrants make the effort to travel across a big city to do experiments in a classroom, an activity they will never have done before in a place they will never have been before, all for the promise of about half a day's income. To do this might well select on very opportunistic people who trust their own judgment and are used to taking risks and trying different things.

Opportunism would then be associated with risk-taking and with trusting one's own judgment enough to lend money to friends, i.e., observed trust behavior, which fits the observed pattern of sample selectivity in Tables 1 and 2. Yet opportunism might also lead that same person to be less trusted and helped by others, making it less likely that spouses will help them to be self-employed and that they cannot become self-employed even if they have the wealth to afford to be one. This fits the pattern of Table 3 where the experimental participants who were married and wealthy were found less likely to be self-employed than the comparable nonparticipants, something that would be counterintuitive in most circumstances but not in urban China, where becoming self-employed is mainly about being seen as sufficiently trustworthy and stable by the family and by partners whose investments and help are needed to succeed in business. Finally, opportunism might help the migrant to become wealthier in the absence of family and friends close by because that is the advantage of opportunism, but might be counterproductive when one is in more familiar territory where there are lots of potential friends and family members who could help. This rationalizes the results of Table 4, where it was found that migrants who came to the experiment and who originated from far away were wealthier, while the migrants who came to the experiment and who originated from nearby were poorer. This explanation is close to that of Slonim et al. (2013), who speculated that intellectual curiosity might have a lot to do with what kind of student shows up to university lab experiments. 
Without direct good measures of such related traits as curiosity or opportunism though, we can here only note that the results seem consistent with such a hypothesis and that future studies looking at selectivity might want to measure such traits in their baseline population.

\section{Discussion and Conclusion}

In this paper, we looked at who among a set of surveyed Chinese migrants in 15 major Chinese cities showed up for artefactual field experiments, and whether their regression coefficients on two particular outcomes of interest (self-employment and distance of migration) differed.

We found significant differences in terms of both composition and regression coefficients. The participants who showed up were more educated, less likely to be self-employed, more likely to lend money to friends, to work for bigger firms, and to work fewer hours than the more general population. The regression coefficients in standard analyses of entrepreneurship and migration distance differed significantly, indicating that inferences drawn from experimental samples may not in general hold for more representative groups of the population. Though the differences were usually relatively small, some particular differences in coefficients were substantial, such as the importance of marriage for entrepreneurship and the importance of wealth for the distance of migration.

In this paper, the show-up rate in the artefactual field experiment was about $1 / 3$, which is high relative to other papers that had also reported response rates (e.g., Slonim et al. 2013). We suspect that our show-up rate is also high relative to artefactual field experiments in developing 
countries because the subjects already had already agreed to a long interview and were promised a relatively large show-up fee as an incentive to come to the experiments. ${ }^{14}$

As a result of the high show-up rate, one might expect the sample that showed up for the artefactual field experiments to be relatively representative of the underlying survey population, meaning we should probably expect bigger effects for settings with lower show-up rates.

Our study thus casts additional doubt on the generalizability of artefactual field experiments in developing country settings and suggests that traits like opportunism and curiosity might be involved, making it important to measure them. More generally, it brings into focus the importance of selectivity in socioeconomic research based on voluntary cooperation.

\footnotetext{
${ }^{14}$ Unfortunately, since most artefactual field experiments do not report the show-up rates, comparisons are difficult. Based on the exchanges we had with various authors who conducted artefactual field experiments in developing countries, the show-up rates in artefactual experiments vary drastically. We would recommend that future papers report the show-up rates so readers can assess the extent to which selection into experiments may play a role.
} 


\section{Reference}

Anderson, J., Burks, S. V., Carpenter, J., Götte, L., Maurer, K., Nosenzo, D. \& Rustichini, A. (2013). Self-selection and variations in the laboratory measurement of other-regarding preferences across subject pools: evidence from one college student and two adult samples. Experimental Economics, 16(2), 170-189.

Andersen, S., Harrison, G.W., Lau, M.I., Rutström, E., 2009. "Preference heterogeneity in experiments: comparing the field and laboratory". Journal of Economic Behavior and Organization. 73 (2), 209-229.

Ashraf, N., Karlan, D., \& Yin, W. (2006). "Tying odysseus to the mast: Evidence from a commitment savings product in the Philippines". Quarterly Journal of Economics, 121(2), 635-672.

Baran, Nicole, Paola Sapienza, and Luigi Zingales (2010). "Can We Infer Social Preferences from the Lab? Evidence from the Trust Game”, CEPR Discussion Paper No. DP7634.

Barsky, R. B., Juster, F. T., Kimball, M. S., \& Shapiro, M. D. (1997). "Preference parameters and behavioral heterogeneity: An experimental approach in the health and retirement study". The Quarterly Journal of Economics, 112(2), 537-579.

Belot, Michèle, Raymond Duch and Luis Miller (2010). "Who Should be Called to the Lab? A comprehensive comparison of students and non-students in classic experimental games". Nuffield centre for experimental social sciences discussion paper series 2010-001

Benz, M. and S. Meier. (2008). "Do People Behave in Experiments as in the Field? Evidence from Donations”, Experimental Economics, 11, $268\{281$.

Camerer, C., \& Lovallo, D. (1999). "Overconfidence and excess entry: An experimental approach”. The American Economic Review, 89(1), pp. 306-318.

Cardenas, J. C., \& Carpenter, J. (2008). Behavioural development economics: lessons from field labs in the developing world. The Journal of Development Studies, 44(3), 311-338.

Carpenter, J. P., Burks, S., \& Verhoogen, E. (2005). Comparing students to workers: The effects of social framing on behavior in distribution games (Vol. 10, pp. 261-289). Emerald Group Publishing Limited.

Carpenter, Jeff, Cristina Connolly and Caitlin Myers (2008). "Altruistic Behavior in a Representative Dictator Experiment”, Experimental Economics, 11(3), 282-298.

Carpenter, Jeffrey; Amrita Daniere and Lois Takahashi. (2004). "Cooperation, Trust, and Social Capital in Southeast Asian Urban Slums”, Journal of Economic Behavior. Org.55:4, pp. 533-51. 
China Telecommunication Report (2007), Ministry of Industry and Information Technology

Cleave, B. L., Nikiforakis, N., \& Slonim, R. (2013). Is there selection bias in laboratory experiments? The case of social and risk preferences. Experimental Economics, 16(3), 372382.

Dasgupta, U., \& Mani, S. (2013). Only Mine or All Ours: An Artefactual Field Experiment on Procedural Altruism (No. dp2013-01). Fordham University, Department of Economics.

Deaton, A. S. (2009). "Instruments of development: Randomization in the tropics, and the search for the elusive keys to economic development", National Bureau of Economic Research.

Dohmen, T. J., Falk, A., Huffman, D., Sunde, U., Schupp, J., \& Wagner, G. G. (2011). "Individual risk attitudes: measurement, determinants, and behavioral consequences". Journal of the European Economic Association, 9(3), 522-550.

Donkers, B., B. Melenberg, and A. V. Soest (2001), "Estimating Risk Attitudes lotteries: a large sample approach". Journal of Risk and Uncertainty, 22 (2), $165\{195$.

Dulleck, U., Fooken, J., \& He, Y. (2012 ). Public policy and individual labor market discrimination: An artefactual field experiment in China. Unpublished paper, Queensland University of Technology.

Falk, A., Meier, S., \& Zehnder, C. (2013). Do Lab Experiments Misrepresent Social Preferences? The Case of Self-Selected Students Samples. Journal of the European Economic Association, 11(4), 839-852.

von Gaudecker, H. M., van Soest, A., \& Wengström, E. (2012). Experts in experiments. Journal of Risk and Uncertainty, 45(2), 159-190.

Harrison, G. W., \& List, J. A. (2004). "Field experiments". Journal of Economic Literature, 42, 1009-1055(47).

Harrison, G. W., Lau, M. I., \& Elisabet Rutström, E. (2009). "Risk attitudes, randomization to treatment, and self-selection into experiments". Journal of Economic Behavior \& Organization, 70(3), 498-507.

Kagel, J., Battalio, R., Walker, J., 1979. "Volunteer artifacts in experiments in economics: specification of the problem and some initial data from a small scale field experiment". Research in Experimental Economics, 1.

Krawczyk, M. (2011). What brings your subjects to the lab? A field experiment. Experimental Economics, 14(4), 482-489. 
Lazear, E. P., Malmendier, U., \& Weber, R. A. (2012). "Sorting in experiments with application to social preferences". American Economic Journal: Applied Economics, 4(1), 136-163.

Levitt, S. D., \& List, J. A. (2007). "What do laboratory experiments measuring social preferences reveal about the real world?" The Journal of Economic Perspectives, 21(2), 153174.

Liu, E. M. (2013). Time to change what to sow: Risk preferences and technology adoption decisions of cotton farmers in China. Review of Economics and Statistics, 95(4), 1386-1403.

Meng, X., Manning, E., Shi, L., Effendi, Tadjuddin., The great migration: Rural-urban migration in China and Indonesia. Edward Elgar, 2010.

Norton, Edward C., Hua Wang, and Chunrong Ai. (2004) . "Computing interaction effects and standard errors in logit and probit models. " Stata Journal 4 (2004): 154-167.

Peterson, Robert A. (2001). "On the Use of College Students in Social Science Research: Insights from a Second-Order Meta-analysis". Journal of Consumer Research 28:450 461.

Roe, Brian E., Timothy C. Haab, David Q. (2009) . "Beversdorf, Howard H. Gu, and Michael R. Tilley". Risk-attitude Selection Bias in Subject Pools for Experiments Involving Rutström, E. E. (1998). Home-grown values and incentive compatible auction design. International Journal of Game Theory, 27(3), 427-441.

Schechter, L. (2007). "Theft, gift-giving, and trustworthiness: Honesty is its own reward in rural Paraguay". The American Economic Review, 97(5), 1560-1582.

Slonim, R., Wang, C., Garbarino, E., \& Merrett, D. (2013). Opting-in: Participation bias in economic experiments. Journal of Economic Behavior \& Organization, 90, 43-70. 
Table 1 Panel A: Summary Statistics by Experiment Participation

\begin{tabular}{|c|c|c|c|c|}
\hline & \multicolumn{2}{|c|}{ "Sample 1:Household Head Only } & \multicolumn{2}{|c|}{ "Sample 2: All Valid Participants } \\
\hline & (1) & (2) & (3) & (4) \\
\hline & Experiment & Not in & Experiment & Not in \\
\hline & Participants & Experiments & Participants & Experiments \\
\hline \multicolumn{5}{|l|}{ Trust and Risk Taking Measures } \\
\hline \multirow{2}{*}{$\begin{array}{l}\text { Subjective Risk Preference }{ }^{\mathrm{a}} \\
\qquad(0=\text { Risk Averse..10=Risk Seeking })\end{array}$} & 4.399 & $4.117 * * *$ & 4.351 & $4.093 * * *$ \\
\hline & $(2.575)$ & $(2.665)$ & $(2.571)$ & $(2.661)$ \\
\hline Often/Sometimes Lend Money to & 0.712 & $0.676^{* *}$ & 0.713 & $0.674 * *$ \\
\hline Acquaintances and Friends ${ }^{\mathrm{b}}$ & $(0.453)$ & $(0.468)$ & $(0.452)$ & $(0.470)$ \\
\hline \multirow[t]{2}{*}{ Trusting People $(\text { Yes }=1)^{\mathrm{c}}$} & 0.573 & 0.574 & 0.573 & 0.573 \\
\hline & $(0.495)$ & $(0.495)$ & $(0.495)$ & $(0.495)$ \\
\hline \multicolumn{5}{|l|}{ Labor Market Outcome } \\
\hline \multirow[t]{2}{*}{ Self-Employed (Yes=1) } & 0.188 & $0.247 * * *$ & 0.197 & $0.234 * * *$ \\
\hline & $(0.391)$ & $(0.431)$ & $(0.397)$ & $(0.424)$ \\
\hline \multirow[t]{2}{*}{ Total monthly wage (1,000 Yuan) } & 1.782 & 1.857 & 1.770 & 1.812 \\
\hline & $(1.180)$ & $(2.154)$ & $(1.183)$ & $(2.106)$ \\
\hline \multirow[t]{2}{*}{ Weekly work hours } & 59.01 & $61.79 * * *$ & 59.14 & $61.30 * * *$ \\
\hline & (18.94) & $(20.06)$ & $(19.33)$ & $(20.35)$ \\
\hline \multirow{2}{*}{$\begin{array}{l}\text { Size of Work Unit has } \\
\qquad 5 \text { employees }\end{array}$} & 0.237 & $0.292 * * *$ & 0.254 & $0.304 * * *$ \\
\hline & $(0.425)$ & $(0.455)$ & $(0.435)$ & $(0.460)$ \\
\hline Size of Work Unit between & 0.325 & 0.303 & 0.320 & 0.298 \\
\hline 5-50 employees & $(0.469)$ & $(0.459)$ & $(0.467)$ & $(0.457)$ \\
\hline \multirow{2}{*}{$\begin{array}{l}\text { Size of Work Unit has } \\
\text { above } 50 \text { employees }\end{array}$} & 0.438 & $0.405^{* *}$ & 0.425 & $0.398^{*}$ \\
\hline & $(0.496)$ & $(0.491)$ & $(0.495)$ & $(0.490)$ \\
\hline \multirow[t]{2}{*}{ Hourly wage (Yuan) } & 8.454 & 8.315 & 8.350 & 8.204 \\
\hline & $(5.150)$ & $(8.028)$ & $(5.147)$ & $(7.862)$ \\
\hline
\end{tabular}

Note : Sample 1 consists of only household heads (hh) who were present at the survey. Column 1 consists of hh who participated in the experiments and column 2 consists of hh who did not participate in the experiments. Column 3 consists of all valid experimental participants. Valid participants for a household are those who were present at the survey. Thus, we have their self-reported preference measures. They can be household head, spouse, or close relatives. Column 4 maintains the sample proportion of household members as Column 3 but draws from the non-participating households. Standard deviation is reported in parentheses. Asterisks correspond to p-values from the two-sided t-tests of equality between Columns $1 \& 2$, Columns $3 \& 4 .{ }^{* * *} \mathrm{p}<0.01,{ }^{* *} \mathrm{p}<0.05,{ }^{*} \mathrm{p}<0.1$

a. Question from the survey: "Some people in a society are more likely to take risks while others are less likely. On a scale from zero to ten, where zero indicates you do not take any risks and ten indicates you like to take risks very much, could you please rank your own risk-taking level?"

b. Question from the survey: "Do you lend money or objects to your friends or acquaintances?" The four choices were "usually"; "sometimes"; "seldom"; and "never." Those who answered usually or sometimes would be assigned 1, otherwise 0.

c. Question from the survey: "In general, do you think most people can be trusted or one should be careful when he/she deals with others?" The choices were "Yes, most people can be trusted"; "No, one should be carefull"; and "Do not know." Those who answered "Yes, most people can be trusted" would be assigned 1, otherwise 0 . 
Table 1 Panel B: Summary Statistics by Experiment Participation

\begin{tabular}{|c|c|c|c|c|}
\hline & \multicolumn{2}{|c|}{ "Sample 1:Household Head Only } & \multicolumn{2}{|c|}{ Sample 2: All Valid Participants } \\
\hline & (1) & (2) & (3) & (4) \\
\hline & Experiment & Not In & Experiment & Not In \\
\hline & Participants & Experiments & Participants & Experiments \\
\hline \multicolumn{5}{|l|}{$\begin{array}{l}\text { Individual Characteristics } \\
\text {. }\end{array}$} \\
\hline \multirow[t]{2}{*}{ Female } & 0.321 & 0.326 & 0.350 & 0.362 \\
\hline & $(0.467)$ & $(0.469)$ & $(0.477)$ & $(0.481)$ \\
\hline \multirow[t]{2}{*}{ Age } & 30.88 & $32.14 * * *$ & 30.90 & $31.84 * * *$ \\
\hline & $(9.820)$ & $(10.71)$ & $(9.803)$ & $(10.70)$ \\
\hline \multirow[t]{2}{*}{ Ethnic Minority (yes=1) } & 0.0166 & 0.0205 & 0.0171 & 0.0225 \\
\hline & $(0.128)$ & $(0.142)$ & $(0.130)$ & $(0.148)$ \\
\hline \multirow[t]{2}{*}{ Married (yes $=1$ ) } & 0.530 & $0.575 * * *$ & 0.537 & 0.560 \\
\hline & $(0.499)$ & $(0.494)$ & $(0.499)$ & $(0.496)$ \\
\hline \multirow[t]{2}{*}{ From the same province } & 0.631 & $0.565^{* * *}$ & 0.634 & $0.563^{* * *}$ \\
\hline & $(0.483)$ & $(0.496)$ & $(0.482)$ & $(0.496)$ \\
\hline \multirow{2}{*}{$\begin{array}{l}\text { Distance from the current city to } \\
\text { the hometown }(\mathrm{km})\end{array}$} & 366.2 & $401.4^{* * *}$ & 360.2 & $395.3 * * *$ \\
\hline & $(422.4)$ & $(441.2)$ & $(418.4)$ & $(437.8)$ \\
\hline \multirow{2}{*}{$\begin{array}{l}\text { Distance to the closest major city } \\
\text { from hometown }(\mathrm{km})\end{array}$} & 119.2 & 116.2 & 119.0 & 116.0 \\
\hline & $(74.89)$ & $(72.58)$ & $(74.47)$ & $(72.59)$ \\
\hline \multirow[t]{2}{*}{ Network in cities ('100 persons) ${ }^{\mathrm{d}}$} & 0.0359 & 0.0364 & 0.0363 & 0.0367 \\
\hline & $(0.0695)$ & $(0.0918)$ & $(0.0732)$ & $(0.0925)$ \\
\hline \multirow[t]{2}{*}{ Years of Education } & 9.752 & $9.301 * * *$ & 9.710 & $9.299 * * *$ \\
\hline & $(2.607)$ & $(2.495)$ & $(2.613)$ & $(2.507)$ \\
\hline \multirow[t]{2}{*}{ Estimated Wealth (Yuan) ${ }^{\mathrm{e}}$} & 12,919 & 11,797 & 15,208 & 12,912 \\
\hline & $(92,634)$ & $(59,536)$ & $(98,836)$ & $(62,648)$ \\
\hline \multirow[t]{2}{*}{ With Reported Wealth $=0$} & 0.0187 & 0.0229 & 0.0189 & 0.0225 \\
\hline & $(0.136)$ & $(0.150)$ & $(0.136)$ & $(0.148)$ \\
\hline \multirow[t]{2}{*}{ Time Elapsed since Migrating (Years) } & 8.238 & 8.518 & 8.183 & 8.295 \\
\hline & $(6.482)$ & $(6.832)$ & $(6.442)$ & $(6.662)$ \\
\hline Observations & 1601 & 3366 & 1693 & 3513 \\
\hline
\end{tabular}

Note: Sample 1 consists of only household heads (hh) who were present at the survey. Column 1 consists of hh who participated in the experiments and column 2 consists of hh who did not participate in the experiments. Column 3 consists of all valid experimental participants. Valid participants for a household are those who were present at the survey. Thus, we have their self-reported preference measures. They can be household head, spouse or close relatives. Column 4 maintain the sample proportion of household members as Column 3 but drawn from the non-participating households. Standard deviation is reported in parentheses. Asterisks correspond to $\mathrm{p}$-values from the two sided t-tests of equality between Columns $1 \& 2$, Column $3 \& 4 . . * * * \mathrm{p}<0.01, * * \mathrm{p}<0.05, * \mathrm{p}<0.1$

d. Question from the survey: how many people who reside in urban area have you contacted/phoned/visited/greeted during Chinese New Year?

e.Wealth is estimated based on the market value of durable goods \& properties owned in urban area. 
Table 2: Linear Probability Model of Participating in Experiments

\begin{tabular}{|c|c|c|c|c|c|c|c|c|}
\hline & Sample 1 & & & & Sample 2 & & & \\
\hline & $(1)$ & $(2)$ & $(3)$ & $(4)$ & $(5)$ & $(6)$ & $(7)$ & $(8)$ \\
\hline $\begin{array}{l}\text { Subjective Risk Preference } \\
(0=\text { Risk Averse..10=Risk Seeking) }\end{array}$ & $\begin{array}{l}0.009 * * * \\
(0.003)\end{array}$ & $\begin{array}{l}0.004 \\
(0.003)\end{array}$ & $\begin{array}{l}0.004 \\
(0.003)\end{array}$ & $\begin{array}{l}0.005 \\
(0.003)\end{array}$ & $\begin{array}{l}0.008 * * * \\
(0.003)\end{array}$ & $\begin{array}{l}0.003 \\
(0.003)\end{array}$ & $\begin{array}{l}0.003 \\
(0.002)\end{array}$ & $\begin{array}{l}0.004 \\
(0.003)\end{array}$ \\
\hline $\begin{array}{l}\text { Often/Sometimes Lend Money } \\
\text { to Acquaintances and Friends }\end{array}$ & $\begin{array}{l}0.030 * * \\
(0.013)\end{array}$ & $\begin{array}{l}0.023 \\
(0.015)\end{array}$ & $\begin{array}{l}0.024 \\
(0.016)\end{array}$ & $\begin{array}{l}0.025 \\
(0.016)\end{array}$ & $\begin{array}{l}0.034 * * * \\
(0.013)\end{array}$ & $\begin{array}{l}0.030 * * \\
(0.015)\end{array}$ & $\begin{array}{l}0.031 * * \\
(0.014)\end{array}$ & $\begin{array}{l}0.032 * * \\
(0.016)\end{array}$ \\
\hline Trusting People $($ Yes $=1)$ & $\begin{array}{l}-0.013 \\
(0.014)\end{array}$ & $\begin{array}{l}-0.022 \\
(0.014)\end{array}$ & $\begin{array}{l}-0.022 \\
(0.014)\end{array}$ & $\begin{array}{l}-0.020 \\
(0.016)\end{array}$ & $\begin{array}{l}-0.012 \\
(0.014)\end{array}$ & $\begin{array}{l}-0.021 \\
(0.013)\end{array}$ & $\begin{array}{l}-0.021 \\
(0.014)\end{array}$ & $\begin{array}{l}-0.019 \\
(0.016)\end{array}$ \\
\hline Female & & $\begin{array}{l}-0.021 * \\
(0.013)\end{array}$ & $\begin{array}{l}-0.021 \\
(0.015)\end{array}$ & $\begin{array}{l}-0.021 \\
(0.018)\end{array}$ & & $\begin{array}{l}-0.027 * * \\
(0.013)\end{array}$ & $\begin{array}{l}-0.027^{* *} \\
(0.013)\end{array}$ & $\begin{array}{l}-0.028 \\
(0.019)\end{array}$ \\
\hline Age & & $\begin{array}{l}0.013 * * * \\
(0.005)\end{array}$ & $\begin{array}{l}0.012 * * * \\
(0.005)\end{array}$ & $\begin{array}{l}0.012 * \\
(0.007)\end{array}$ & & $\begin{array}{l}0.013 * * * \\
(0.004)\end{array}$ & $\begin{array}{l}0.013 * * \\
(0.005)\end{array}$ & $\begin{array}{l}0.013^{*} \\
(0.007)\end{array}$ \\
\hline (Age)2 & & $\begin{array}{l}-0.000 * * * \\
(0.000)\end{array}$ & $\begin{array}{l}-0.000 * * * \\
(0.000)\end{array}$ & $\begin{array}{l}-0.000^{*} \\
(0.000)\end{array}$ & & $\begin{array}{l}-0.000 * * * \\
(0.000)\end{array}$ & $\begin{array}{l}-0.000^{* *} * \\
(0.000)\end{array}$ & $\begin{array}{l}-0.000 * \\
(0.000)\end{array}$ \\
\hline Ethnic Minority $(Y e s=1)$ & & $\begin{array}{l}-0.008 \\
(0.046)\end{array}$ & $\begin{array}{l}-0.010 \\
(0.052)\end{array}$ & $\begin{array}{l}-0.024 \\
(0.060)\end{array}$ & & $\begin{array}{l}0.011 \\
(0.052)\end{array}$ & $\begin{array}{l}0.010 \\
(0.048)\end{array}$ & $\begin{array}{l}-0.004 \\
(0.062)\end{array}$ \\
\hline Married & & $\begin{array}{l}-0.011 \\
(0.019)\end{array}$ & $\begin{array}{l}-0.011 \\
(0.018)\end{array}$ & $\begin{array}{l}-0.006 \\
(0.021)\end{array}$ & & $\begin{array}{l}-0.011 \\
(0.019)\end{array}$ & $\begin{array}{l}-0.011 \\
(0.019)\end{array}$ & $\begin{array}{l}-0.006 \\
(0.022)\end{array}$ \\
\hline Years of Education & & $\begin{array}{l}0.009 * * * \\
(0.003)\end{array}$ & $\begin{array}{l}0.008 * * * \\
(0.003)\end{array}$ & $\begin{array}{l}0.008 * * \\
(0.004)\end{array}$ & & $\begin{array}{l}0.009 * * * \\
(0.003)\end{array}$ & $\begin{array}{l}0.009 * * * \\
(0.002)\end{array}$ & $\begin{array}{l}0.009 * * * \\
(0.003)\end{array}$ \\
\hline Hourly wage & & $\begin{array}{l}-0.001 \\
(0.001)\end{array}$ & $\begin{array}{l}-0.001 \\
(0.001)\end{array}$ & $\begin{array}{l}-0.001 \\
(0.001)\end{array}$ & & $\begin{array}{l}-0.001 \\
(0.001)\end{array}$ & $\begin{array}{l}-0.001 \\
(0.001)\end{array}$ & $\begin{array}{l}-0.001 \\
(0.001)\end{array}$ \\
\hline Log (W ealth) & & $\begin{array}{l}-0.001 \\
(0.004)\end{array}$ & $\begin{array}{l}-0.002 \\
(0.004)\end{array}$ & $\begin{array}{l}-0.003 \\
(0.005)\end{array}$ & & $\begin{array}{l}-0.001 \\
(0.005)\end{array}$ & $\begin{array}{l}-0.001 \\
(0.005)\end{array}$ & $\begin{array}{l}-0.003 \\
(0.005)\end{array}$ \\
\hline Weekly Work Hours & & $\begin{array}{l}-0.001 * * * \\
(0.000)\end{array}$ & & $\begin{array}{l}-0.001 \\
(0.001)\end{array}$ & & $\begin{array}{l}-0.001 * * * \\
(0.000)\end{array}$ & & $\begin{array}{l}-0.001 \\
(0.001)\end{array}$ \\
\hline $\begin{array}{l}\text { Weekly Work Hours 2nd Quartiles } \\
\text { (48-60 hours) }\end{array}$ & & & $\begin{array}{l}-0.043 * * \\
(0.022)\end{array}$ & & & & $\begin{array}{l}-0.033 \\
(0.024)\end{array}$ & \\
\hline $\begin{array}{l}\text { Weekly Work Hours 3rd Quartiles } \\
(61-70 \text { hours })\end{array}$ & & & $\begin{array}{l}-0.065^{* *} \\
(0.025)\end{array}$ & & & & $\begin{array}{l}-0.055^{* *} \\
(0.026)\end{array}$ & \\
\hline $\begin{array}{l}\text { Weekly Work Hours 4th Quartiles } \\
\text { (70 hours above) }\end{array}$ & & & $\begin{array}{l}-0.086 * * * \\
(0.023)\end{array}$ & & & & $\begin{array}{l}-0.076^{* * *} \\
(0.026)\end{array}$ & \\
\hline $\begin{array}{l}\text { Size of Work Unit between } \\
5-50 \text { employees }\end{array}$ & & $\begin{array}{l}0.055^{* * * *} \\
(0.017)\end{array}$ & $\begin{array}{l}0.054 * * * \\
(0.018)\end{array}$ & $\begin{array}{l}0.081 * * * \\
(0.028)\end{array}$ & & $\begin{array}{l}0.051 * * * \\
(0.019)\end{array}$ & $\begin{array}{l}0.048 * * * \\
(0.019)\end{array}$ & $\begin{array}{l}0.075^{* *} \\
(0.033)\end{array}$ \\
\hline $\begin{array}{l}\text { Size of Work Unit } \\
\text { above } 50 \text { employees }\end{array}$ & & $\begin{array}{l}0.086^{* * * *} \\
(0.018)\end{array}$ & $\begin{array}{l}0.083 * * * \\
(0.018)\end{array}$ & $\begin{array}{l}0.102 * * * \\
(0.027)\end{array}$ & & $\begin{array}{l}0.082 * * * \\
(0.018)\end{array}$ & $\begin{array}{l}0.076^{* * * *} \\
(0.020)\end{array}$ & $\begin{array}{l}0.097 * * * \\
(0.033)\end{array}$ \\
\hline District of Work FE ${ }^{\mathrm{a}}$ & & & & $\mathrm{X}$ & & & & $\mathrm{X}$ \\
\hline City FE & & $\mathrm{X}$ & $\mathrm{X}$ & & & $\mathrm{X}$ & $\mathrm{X}$ & \\
\hline $\begin{array}{l}\mathrm{H} 0 \text { : Trust }=\text { Ris } \mathrm{k}=\text { Lending } \text { Money }=0 \\
\mathrm{~b}\end{array}$ & 0.000 & 0.025 & 0.123 & 0.071 & 0.000 & 0.0873 & 0.0431 & 0.0505 \\
\hline H0: District of Work FE $=0^{c}$ & & & & 0.000 & & & & 0.000 \\
\hline R-squared & 0.003 & 0.065 & 0.066 & 0.112 & 0.003 & 0.063 & 0.064 & 0.111 \\
\hline Number of Observations & 4,743 & 4,743 & 4,743 & 4,491 & 4,952 & 4,952 & 4,952 & 4,691 \\
\hline
\end{tabular}

Note: $* * * \mathrm{p}<0.01, * * \mathrm{p}<0.05, * \mathrm{p}<0.1$. Coefficients from linear probability model are reported. Columns 4 and 8 have fewer observations since some people's districts of work location are unidentified or some districts have only one observation, thus are dropped from the analysis. All regressions include a dummy indicating whether wealth is recorded as zero or not. The omitted work hours are those who work less than 48 hours a week. The omitted work units are those with less than 5 employees. Bootstrap standard errors are in parentheses.

a. A set of dummies for city-district of work location.

b. P-values of joint significance test (risk preference $=$ lend money $=$ trusting people $=0$ )

c. P-values of joint significance test (Dis trict of Work Dummies $=0$ ) 
Table 3: Determinants of Self-Employment

\begin{tabular}{|c|c|c|c|c|c|c|}
\hline & & Sample 1 & & & Sample 2 & \\
\hline & (1) & (2) & (3) & (4) & (5) & (6) \\
\hline Experiment Participants (EP) & & 0.016 & 0.047 & & -0.046 & -0.061 \\
\hline & & $(0.155)$ & $(0.161)$ & & $(0.137)$ & $(0.143)$ \\
\hline Subjective Risk Preference & 0.002 & 0.001 & 0.002 & 0.003 & 0.002 & 0.003 \\
\hline$(0=$ Risk Averse.. $10=$ Risk Seeking) & $(0.002)$ & $(0.003)$ & $(0.002)$ & $(0.002)$ & $(0.003)$ & $(0.002)$ \\
\hline Often/Sometimes Lend Money & 0.001 & -0.004 & -0.007 & 0.000 & -0.009 & -0.011 \\
\hline to Acquaintances and Friends & $(0.013)$ & $(0.016)$ & $(0.016)$ & $(0.011)$ & $(0.014)$ & $(0.014)$ \\
\hline Trusting People (Yes=1) & $-0.037 * * *$ & $-0.047 * * *$ & $-0.043 * * *$ & $-0.038 * * *$ & $-0.052 * * *$ & $-0.047 * * *$ \\
\hline & $(0.011)$ & $(0.014)$ & $(0.013)$ & $(0.012)$ & $(0.014)$ & $(0.011)$ \\
\hline Female & 0.004 & 0.005 & 0.008 & 0.020 & 0.017 & 0.020 \\
\hline & $(0.012)$ & $(0.016)$ & $(0.012)$ & $(0.012)$ & $(0.015)$ & $(0.012)$ \\
\hline Age & $0.015^{* * *}$ & $0.013 * *$ & $0.014 * * *$ & $0.017 * * *$ & $0.015^{* * *}$ & $0.015^{* * *}$ \\
\hline & $(0.004)$ & $(0.005)$ & $(0.005)$ & $(0.004)$ & $(0.004)$ & $(0.005)$ \\
\hline (Age) 2 & $-0.000 * * *$ & $-0.000 * *$ & $-0.000 * * *$ & $-0.000 * * *$ & $-0.000 * * *$ & $-0.000 * * *$ \\
\hline & $(0.000)$ & $(0.000)$ & $(0.000)$ & $(0.000)$ & $(0.000)$ & $(0.000)$ \\
\hline Ethnic Minority (yes=1) & -0.014 & -0.037 & -0.037 & -0.009 & -0.052 & -0.054 \\
\hline & $(0.030)$ & $(0.038)$ & $(0.035)$ & $(0.041)$ & $(0.042)$ & $(0.037)$ \\
\hline Married & $0.106^{* * *}$ & $0.128 * * *$ & $0.131 * * *$ & $0.112 * * *$ & $0.131 * * *$ & $0.135^{* * *}$ \\
\hline & $(0.015)$ & $(0.020)$ & $(0.020)$ & $(0.015)$ & $(0.018)$ & $(0.020)$ \\
\hline Year of edu & $-0.017 * * *$ & $-0.015 * * *$ & $-0.015 * * *$ & $-0.019 * * *$ & $-0.017 * * *$ & $-0.017 * * *$ \\
\hline & $(0.002)$ & $(0.003)$ & $(0.003)$ & $(0.003)$ & $(0.003)$ & $(0.003)$ \\
\hline Log(Wealth) & $0.064 * * *$ & $0.071 * * *$ & $0.069 * * *$ & $0.062 * * *$ & $0.069 * * *$ & $0.066^{* * *}$ \\
\hline & $(0.004)$ & $(0.005)$ & $(0.004)$ & $(0.004)$ & $(0.004)$ & $(0.005)$ \\
\hline Years since Migrating to City & $0.004 * * *$ & $0.005 * * *$ & $0.005 * * *$ & $0.004 * * *$ & $0.005 * * *$ & $0.005 * * *$ \\
\hline & $(0.001)$ & $(0.001)$ & $(0.002)$ & $(0.001)$ & $(0.001)$ & $(0.002)$ \\
\hline Size of Social Network & -0.011 & -0.010 & -0.002 & -0.011 & -0.006 & 0.004 \\
\hline & $(0.021)$ & $(0.025)$ & $(0.024)$ & $(0.021)$ & $(0.027)$ & $(0.024)$ \\
\hline EP* Subjective Risk Preference & & 0.005 & 0.003 & & 0.003 & 0.001 \\
\hline & & $(0.004)$ & $(0.005)$ & & $(0.005)$ & $(0.004)$ \\
\hline EP* Lending Money & & 0.023 & 0.026 & & 0.034 & $0.039^{*}$ \\
\hline & & $(0.025)$ & $(0.027)$ & & $(0.028)$ & $(0.023)$ \\
\hline EP* Trusting People & & 0.029 & 0.021 & & $0.042 * *$ & 0.032 \\
\hline & & $(0.023)$ & $(0.022)$ & & $(0.020)$ & $(0.020)$ \\
\hline EP*Female & & -0.011 & -0.023 & & 0.002 & -0.011 \\
\hline & & $(0.025)$ & $(0.022)$ & & $(0.023)$ & $(0.024)$ \\
\hline EP*Age & & 0.005 & 0.006 & & 0.007 & 0.009 \\
\hline & & $(0.009)$ & $(0.009)$ & & $(0.007)$ & $(0.008)$ \\
\hline EP*Age2 & & -0.000 & -0.000 & & -0.000 & -0.000 \\
\hline & & $(0.000)$ & $(0.000)$ & & $(0.000)$ & $(0.000)$ \\
\hline EP*Minority & & 0.097 & 0.099 & & $0.151 * *$ & $0.154 * *$ \\
\hline & & $(0.069)$ & $(0.071)$ & & $(0.076)$ & $(0.076)$ \\
\hline EP*Married & & $-0.071 * *$ & $-0.076^{* *}$ & & $-0.063 * *$ & $-0.072 * *$ \\
\hline & & $(0.034)$ & $(0.034)$ & & $(0.028)$ & $(0.035)^{2}$ \\
\hline EP*Years of Education & & -0.003 & -0.004 & & -0.004 & -0.003 \\
\hline & & $(0.004)$ & $(0.005)$ & & $(0.005)$ & $(0.005)$ \\
\hline
\end{tabular}




\begin{tabular}{|c|c|c|c|c|c|c|}
\hline \multicolumn{2}{|l|}{ EP*Married } & $\begin{array}{l}-0.071 * * \\
(0.034)\end{array}$ & $\begin{array}{l}-0.076^{* *} \\
(0.034)\end{array}$ & & $\begin{array}{l}-0.063^{* *} \\
(0.028)\end{array}$ & $\begin{array}{l}-0.072 * * \\
(0.035)\end{array}$ \\
\hline \multicolumn{2}{|l|}{ EP*Years of Education } & $\begin{array}{l}-0.003 \\
(0.004)\end{array}$ & $\begin{array}{l}-0.004 \\
(0.005)\end{array}$ & & $\begin{array}{l}-0.004 \\
(0.005)\end{array}$ & $\begin{array}{l}-0.003 \\
(0.005)\end{array}$ \\
\hline \multicolumn{2}{|l|}{ EP*log(wealth) } & $\begin{array}{l}-0.024 * * * \\
(0.007)\end{array}$ & $\begin{array}{l}-0.019 * * \\
(0.008)\end{array}$ & & $\begin{array}{l}-0.021 * * * \\
(0.007)\end{array}$ & $\begin{array}{l}-0.015^{*} \\
(0.007)\end{array}$ \\
\hline \multicolumn{2}{|l|}{ EP*Years since Migrating to City } & $\begin{array}{l}-0.003 \\
(0.003)\end{array}$ & $\begin{array}{l}-0.003 \\
(0.003)\end{array}$ & & $\begin{array}{l}-0.004 \\
(0.003)\end{array}$ & $\begin{array}{l}-0.005^{*} \\
(0.003)\end{array}$ \\
\hline \multicolumn{2}{|l|}{ EP*Network Size } & $\begin{array}{l}-0.013 \\
(0.042)\end{array}$ & $\begin{array}{l}-0.037 \\
(0.039)\end{array}$ & & $\begin{array}{l}-0.028 \\
(0.039)\end{array}$ & $\begin{array}{l}-0.059 \\
(0.042)\end{array}$ \\
\hline Constant & $\begin{array}{l}-0.465^{* * *} \\
(0.081)\end{array}$ & $\begin{array}{l}-0.459 * * * \\
(0.097)\end{array}$ & $\begin{array}{l}-0.482 * * * \\
(0.079)\end{array}$ & $\begin{array}{l}-0.478 * * * \\
(0.071)\end{array}$ & $\begin{array}{l}-0.455^{* * *} \\
(0.086)\end{array}$ & $\begin{array}{l}-0.463 * * * \\
(0.090)\end{array}$ \\
\hline City Fixed Effect (FE) & $\mathrm{X}$ & $\mathrm{X}$ & $\mathrm{X}$ & $\mathrm{X}$ & $\mathrm{X}$ & $\mathrm{X}$ \\
\hline EP*City Dummies & & & $\mathrm{X}$ & & & $\mathrm{X}$ \\
\hline H0: Trust $=$ Risk $=$ Lending Money $=0^{\mathrm{a}}$ & 0.002 & 0.006 & 0.013 & 0.015 & 0.002 & 0.0001 \\
\hline H0: EP and EP interaction terms $=0^{b}$ & & 0.000 & 0.000 & & 0.000 & 0.000 \\
\hline $\mathrm{H} 0: \mathrm{EP} *$ Trust $=\mathrm{EP} *$ Risk $=\mathrm{EP} *$ lending & & 0.193 & 0.450 & & 0.093 & 0.047 \\
\hline money $=0^{c}$ & & & & & & \\
\hline Observations & 4,722 & 4,722 & 4,722 & 4,934 & 4,934 & 4,934 \\
\hline R-squared & 0.233 & 0.242 & 0.249 & 0.242 & 0.251 & 0.257 \\
\hline
\end{tabular}

Note: ${ }^{* * *} \mathrm{p}<0.01,{ }^{* *} \mathrm{p}<0.05,{ }^{*} \mathrm{p}<0.1$. Coefficients from linear probability model are estimated. All regressions include a dummy indicating whether wealth is recorded as zero or not. In Columns 2, 3, 5 and 6, the interaction term between EP and wealth equals 0 dummies are also included. Bootstrap standard errors are in parentheses.

a. P-values from F-test for the joint significance of three preference parameters are reported. (Trust $=$ Risk $=$ Lending money $=0$ )

b. P-values from F-test for the joint signficance of all in-experiment interaction terms and in-experiment dummy are reported. (EP and EP interaction terms $=0$ )

c. P-values from F-test for the joint significance of in-experiment * preferences interaction terms are reported. $(\mathrm{EP} *$ Trust $=\mathrm{EP} * \mathrm{Risk}=\mathrm{EP} *$ lending money $=0)$ 
Table 4: Determinants of Log (Distance of Migration)

\begin{tabular}{|c|c|c|c|c|c|c|}
\hline & \multicolumn{3}{|c|}{ Sample 1} & \multicolumn{3}{|c|}{$\underline{\text { Sample } 2}$} \\
\hline & (1) & (2) & (3) & (4) & $(5)$ & (6) \\
\hline Experiment Participants (EP) & & $\begin{array}{l}-1.953 * * * \\
(0.485)\end{array}$ & $\begin{array}{l}-1.661 * * * \\
(0.552)\end{array}$ & & $\begin{array}{l}-1.729 * * * \\
(0.438)\end{array}$ & $\begin{array}{l}-1.430 * * * \\
(0.493)\end{array}$ \\
\hline $\begin{array}{l}\text { Subjective Risk Preference } \\
\qquad(0=\text { Risk Averse.. 10=Risk Seeking) }\end{array}$ & $\begin{array}{l}0.004 \\
(0.006)\end{array}$ & $\begin{array}{l}-0.003 \\
(0.008)\end{array}$ & $\begin{array}{l}-0.002 \\
(0.007)\end{array}$ & $\begin{array}{l}0.003 \\
(0.006)\end{array}$ & $\begin{array}{l}-0.002 \\
(0.007)\end{array}$ & $\begin{array}{l}-0.001 \\
(0.006)\end{array}$ \\
\hline $\begin{array}{l}\text { Often/Sometimes Lend Money } \\
\text { to Acquaintances and Friends }\end{array}$ & $\begin{array}{l}-0.054 * * \\
(0.023)\end{array}$ & $\begin{array}{l}-0.060 \\
(0.042)\end{array}$ & $\begin{array}{l}-0.065^{*} \\
(0.037)\end{array}$ & $\begin{array}{l}-0.056^{* *} \\
(0.028)\end{array}$ & $\begin{array}{l}-0.059 * \\
(0.034)\end{array}$ & $\begin{array}{l}-0.063 \\
(0.039)\end{array}$ \\
\hline Trusting People $(Y e s=1)$ & $\begin{array}{l}-0.024 \\
(0.028)\end{array}$ & $\begin{array}{l}-0.018 \\
(0.038)\end{array}$ & $\begin{array}{l}-0.017 \\
(0.036)\end{array}$ & $\begin{array}{l}-0.023 \\
(0.028)\end{array}$ & $\begin{array}{l}-0.009 \\
(0.029)\end{array}$ & $\begin{array}{l}-0.010 \\
(0.035)\end{array}$ \\
\hline Female & $\begin{array}{l}-0.106^{* * *} \\
(0.034)\end{array}$ & $\begin{array}{l}-0.120 * * * \\
(0.032)\end{array}$ & $\begin{array}{l}-0.114 * * * \\
(0.034)\end{array}$ & $\begin{array}{l}-0.116 * * * \\
(0.026)\end{array}$ & $\begin{array}{l}-0.125^{* * *} \\
(0.035)\end{array}$ & $\begin{array}{l}-0.120 * * * \\
(0.033)\end{array}$ \\
\hline Age & $\begin{array}{l}0.009 \\
(0.010)\end{array}$ & $\begin{array}{l}0.001 \\
(0.012)\end{array}$ & $\begin{array}{l}0.002 \\
(0.013)\end{array}$ & $\begin{array}{l}0.009 \\
(0.009)\end{array}$ & $\begin{array}{l}0.004 \\
(0.011)\end{array}$ & $\begin{array}{l}0.005 \\
(0.013)\end{array}$ \\
\hline (Age) 2 & $\begin{array}{l}-0.000 * \\
(0.000)\end{array}$ & $\begin{array}{l}-0.000 \\
(0.000)\end{array}$ & $\begin{array}{l}-0.000 \\
(0.000)\end{array}$ & $\begin{array}{l}-0.000 * \\
(0.000)\end{array}$ & $\begin{array}{l}-0.000 \\
(0.000)\end{array}$ & $\begin{array}{l}-0.000 \\
(0.000)\end{array}$ \\
\hline Ethnic Minority (yes $=1$ ) & $\begin{array}{l}0.717 * * * \\
(0.142)\end{array}$ & $\begin{array}{l}0.832 * * * \\
(0.160)\end{array}$ & $\begin{array}{l}0.830 * * * \\
(0.182)\end{array}$ & $\begin{array}{l}0.715^{* * *} \\
(0.136)\end{array}$ & $\begin{array}{l}0.842^{* * *} \\
(0.156)\end{array}$ & $\begin{array}{l}0.843 * * * \\
(0.165)\end{array}$ \\
\hline Married & $\begin{array}{l}-0.015 \\
(0.039)\end{array}$ & $\begin{array}{l}-0.012 \\
(0.046)\end{array}$ & $\begin{array}{l}-0.011 \\
(0.048)\end{array}$ & $\begin{array}{l}-0.008 \\
(0.040)\end{array}$ & $\begin{array}{l}-0.011 \\
(0.049)\end{array}$ & $\begin{array}{l}-0.012 \\
(0.057)\end{array}$ \\
\hline Year of Education & $\begin{array}{l}-0.000 \\
(0.006)\end{array}$ & $\begin{array}{l}-0.004 \\
(0.008)\end{array}$ & $\begin{array}{l}-0.004 \\
(0.007)\end{array}$ & $\begin{array}{l}-0.000 \\
(0.006)\end{array}$ & $\begin{array}{l}-0.005 \\
(0.008)\end{array}$ & $\begin{array}{l}-0.004 \\
(0.007)\end{array}$ \\
\hline Log(Wealth) & $\begin{array}{l}-0.021 * * \\
(0.009)\end{array}$ & $\begin{array}{l}-0.043 * * * \\
(0.011)\end{array}$ & $\begin{array}{l}-0.044^{* * *} \\
(0.010)\end{array}$ & $\mid \begin{array}{l}-0.020^{* *} \\
(0.010)\end{array}$ & $\begin{array}{l}-0.040^{* * *} \\
(0.010)\end{array}$ & $\begin{array}{l}-0.042^{* * *} \\
(0.011)\end{array}$ \\
\hline Size of Social Network & $\begin{array}{l}0.023 \\
(0.081)\end{array}$ & $\begin{array}{l}0.051 \\
(0.097)\end{array}$ & $\begin{array}{l}0.047 \\
(0.086)\end{array}$ & $\begin{array}{l}0.010 \\
(0.072)\end{array}$ & $\begin{array}{l}0.051 \\
(0.081)\end{array}$ & $\begin{array}{l}0.049 \\
(0.088)\end{array}$ \\
\hline $\begin{array}{l}\text { Log (Distance to Closest } \\
\text { City from Hometown) }\end{array}$ & $\begin{array}{l}0.643 * * * \\
(0.037)\end{array}$ & $\begin{array}{l}0.587 * * * \\
(0.038)\end{array}$ & $\begin{array}{l}0.588^{* * *} \\
(0.045)\end{array}$ & $\begin{array}{l}0.652 * * * \\
(0.033)\end{array}$ & $\begin{array}{l}0.598^{* * *} \\
(0.039)\end{array}$ & $\begin{array}{l}0.598 * * * \\
(0.038)\end{array}$ \\
\hline EP* Subjective Risk Preference & & $\begin{array}{l}0.021^{*} \\
(0.012)\end{array}$ & $\begin{array}{l}0.018 \\
(0.012)\end{array}$ & & $\begin{array}{l}0.018 \\
(0.011)\end{array}$ & $\begin{array}{l}0.014 \\
(0.012)\end{array}$ \\
\hline EP*Lending Money & & $\begin{array}{l}0.017 \\
(0.061)\end{array}$ & $\begin{array}{l}0.034 \\
(0.065)\end{array}$ & & $\begin{array}{l}0.006 \\
(0.060)\end{array}$ & $\begin{array}{l}0.022 \\
(0.067)\end{array}$ \\
\hline EP*Trusting People & & $\begin{array}{l}-0.025 \\
(0.057)\end{array}$ & $\begin{array}{l}-0.021 \\
(0.053)\end{array}$ & & $\begin{array}{l}-0.044 \\
(0.046)\end{array}$ & $\begin{array}{l}-0.037 \\
(0.060)\end{array}$ \\
\hline EP*Female & & $\begin{array}{l}0.050 \\
(0.057)\end{array}$ & $\begin{array}{l}0.023 \\
(0.059)\end{array}$ & & $\begin{array}{l}0.031 \\
(0.059)\end{array}$ & $\begin{array}{l}0.010 \\
(0.062)\end{array}$ \\
\hline EP*Age & & $\begin{array}{l}0.026 \\
(0.021)\end{array}$ & $\begin{array}{l}0.022 \\
(0.020)\end{array}$ & & $\begin{array}{l}0.018 \\
(0.020)\end{array}$ & $\begin{array}{l}0.012 \\
(0.020)\end{array}$ \\
\hline EP*Age2 & & $\begin{array}{l}-0.000 \\
(0.000)\end{array}$ & $\begin{array}{l}-0.000 \\
(0.000)\end{array}$ & & $\begin{array}{l}-0.000 \\
(0.000)\end{array}$ & $\begin{array}{l}-0.000 \\
(0.000)\end{array}$ \\
\hline EP*Minority & & $\begin{array}{l}-0.446^{*} \\
(0.253)\end{array}$ & $\begin{array}{l}-0.427 \\
(0.282)\end{array}$ & & $\begin{array}{l}-0.453^{*} \\
(0.266)\end{array}$ & $\begin{array}{l}-0.439 * \\
(0.254)\end{array}$ \\
\hline
\end{tabular}




\begin{tabular}{|c|c|c|c|c|c|c|}
\hline EP*Married & & $\begin{array}{l}0.005 \\
(0.078)\end{array}$ & $\begin{array}{l}0.010 \\
(0.085)\end{array}$ & & $\begin{array}{l}0.024 \\
(0.082)\end{array}$ & $\begin{array}{l}0.037 \\
(0.090)\end{array}$ \\
\hline EP*Years of Education & & $\begin{array}{l}0.012 \\
(0.012)\end{array}$ & $\begin{array}{l}0.009 \\
(0.012)\end{array}$ & & $\begin{array}{l}0.016 \\
(0.013)\end{array}$ & $\begin{array}{l}0.012 \\
(0.012)\end{array}$ \\
\hline EP*log(wealth) & & $\begin{array}{l}0.063 * * * \\
(0.017)\end{array}$ & $\begin{array}{l}0.067 * * * \\
(0.017)\end{array}$ & & $\begin{array}{l}0.055^{* * *} \\
(0.017)\end{array}$ & $\begin{array}{l}0.059 * * * \\
(0.019)\end{array}$ \\
\hline EP*Network Size & & $\begin{array}{l}-0.057 \\
(0.154)\end{array}$ & $\begin{array}{l}-0.032 \\
(0.143)\end{array}$ & & $\begin{array}{l}-0.093 \\
(0.123)\end{array}$ & $\begin{array}{l}-0.071 \\
(0.134)\end{array}$ \\
\hline $\begin{array}{l}\mathrm{EP} * \log (\text { Distance to Closest City } \\
\text { from Hometown) }\end{array}$ & & $\begin{array}{l}0.167 * * \\
(0.069)\end{array}$ & $\begin{array}{l}0.160 * * \\
(0.068)\end{array}$ & & $\begin{array}{l}0.158 * * \\
(0.062)\end{array}$ & $\begin{array}{l}0.154^{* *} \\
(0.062)\end{array}$ \\
\hline $\begin{array}{l}\text { City Fixed Effect (FE) } \\
\text { EP*City Dummies }\end{array}$ & $\mathrm{X}$ & $\mathrm{X}$ & $\begin{array}{l}X \\
X\end{array}$ & $\mathrm{X}$ & $\mathrm{X}$ & $\begin{array}{l}X \\
X\end{array}$ \\
\hline H0: Trust $=$ Risk $=$ Lending Money $=0^{\mathrm{a}}$ & 0.046 & 0.355 & 0.268 & 0.146 & 0.217 & 0.431 \\
\hline H0: EP and EP interaction terms $=0^{b}$ & & 0.000 & 0.000 & & 0.001 & 0.000 \\
\hline $\begin{array}{l}\mathrm{H} 0: \mathrm{EP} * \text { Trust }=\mathrm{EP} * \text { Risk}=\mathrm{EP} * \text { lending } \\
\text { money }=0^{\mathrm{c}}\end{array}$ & & 0.345 & 0.367 & & 0.324 & 0.643 \\
\hline Observations & 4,823 & 4,823 & 4,823 & 5,040 & 5,040 & 5,040 \\
\hline R-squared & 0.579 & 0.584 & 0.585 & 0.581 & 0.586 & 0.587 \\
\hline
\end{tabular}

Note: ${ }^{* * *} \mathrm{p}<0.01,{ }^{* *} \mathrm{p}<0.05, * \mathrm{p}<0.1$. All regressions include a dummy indicating whether wealth is recorded as zero or not. In Columns 2, 3, 5 and 6, the interaction term between EP and wealth equals 0 dummies are also included. Bootstrapped standard errors are in parentheses.

a. P-values from F-test for the joint significance of three preference parameters are reported.

(Trust $=$ Risk=Lending money $=0$ )

b. P-values from F-test for the joint signficance of all in-experiment interaction terms and in-experiment dummy are reported. (EP and EP interaction terms $=0$ )

c. P-values from F-test for the joint significance of in-experiment preferences interaction terms are 